\title{
Novas Tecnologias e Educação: REA uma possibilidade
}

\author{
Eliane Aparecida de Oliveira ${ }^{1}$
}

"REA são materiais de ensino, aprendizado e pesquisa, em qualquer suporte ou mídia, que estão sob domínio público, ou estão licenciados de maneira aberta, permitindo que sejam utilizados ou adaptados por terceiros. $\mathrm{O}$ uso de formatos técnicos abertos facilita o acesso e reuso potencial dos recursos publicados digitalmente. Recursos educacionais abertos podem incluir cursos completos, partes de cursos, módulos, livros didáticos, artigos de pesquisa, vídeos, testes, software, e qualquer outra ferramenta, material ou técnica que possa apoiar o acesso ao conhecimento.’UNESCO, 2011.

No dia trinta de maio de 2012 foi lançado o primeiro livro sobre Recursos Educacionais Abertos (REA) do Brasil "Recursos Educacionais Abertos: práticas colaborativas e políticas públicas" é uma obra criada em conjunto pela Casa da Cultura Digital e a EDUFBA, foi organizado por Bianca Santana (Instituto Educadigital/Casa de Cultura Digital), Carolina Rossini (Projeto REA Brasil/GPOPAI-USP) e Nelson Pretto (UFBA) e tem como proposta

${ }^{1}$ Mestranda do Programa de Pós Graduação em Ciências Sociais da Universidade Estadual de Maringá/UEM 
promover o debate a cerca dos usos e democratização da internet como recurso para a educação. O livro é composto de artigos copilados por professores, acadêmicos e profissionais do ensino, traz ainda relatos de experiências e entrevistas. Como não podia deixar de ser, foi todo produzido com o uso de softwares e fontes livres e esta disponível na internet para download no site http://livrorea.net.br, nas palavras de seus organizadores, para ser "consumido e apropriado".

Refletir sobre os usos da internet na educação é também pensar sobre a universalização de um ensino de qualidade numa sociedade cada vez mais conectada. O conceito do REA trata da criação de materiais abertos para consulta, uso e adaptação e foi elaborado pela UNESCO em 2002. O livro usa como mote a concepção de educação para todos, dessa forma a produção e compartilhamento de materiais educativos usando internet seria uma via possível de fazer isso acontecer. A análise de políticas públicas para que a internet chegue a todos os espaços onde a educação esta presente, nos permite perceber como o Estado atua para que isso se efetive. O livro nos mostra reflexões nesse sentido já na sua apresentação.

Os autores mostram a necessidade de programas governamentais que criem uma infraestrutura para redes digitais visando propiciar a ligação das escolas com o mundo, salientam ainda que a formação dos professores deve ser pensada em conotação com essa nova realidade, pois estes devem estar aptos a fazer uso das novas tecnologias, bem 
como serem capazes de produzir materiais passiveis de serem remixados. Esclarecem algumas políticas publicas já implementadas no país que, embora insuficientes, permitem que seja possível os primeiros passos em busca de uma rede mais ampla que abarque as necessidades do campo educacional.

O livro é composto de onze artigos e cinco entrevistas, cujos autores possuem concepções singulares a cerca do REA, devido a isso, seu texto propicia ao leitor a possibilidade de criar suas próprias impressões sobre o tema. Embora com olhares diferentes, todos tratam da educação brasileira atual como um modelo a ser pensado e modificado. Visam uma escola mais dinâmica, entendendo a educação como plural, na palavra dos organizadores "Queremos uma escola, cujos muros possam ser assaltados pela diversidade de olhares e de percepções que permitam, de forma quem sabe até contraditória, pensar na ausência do muro e da escola.” (p. 13).

A divisão em artigos, relatos de experiências e entrevistas permite ao leitor escolher o que mais lhe interessa sobre o assunto, sem ter um prejuízo do todo, pois o conceito de recurso educacional aberto aparece de forma clara em todos os textos que compõem o livro. Dessa forma, ele apresenta seis artigos que abordam as práticas educacionais em conjunto com a produção de REA, políticas públicas para educação digital e professores como produtores. Cinco textos produzidos a partir de relatos de experiências que discutem a produção de REA na 
aprendizagem formal e informal, autodidatismo e formação de professores. Por fim, cinco entrevistados falam sobre direitos autorais, políticas públicas e projetos educacionais.

Mais do que propor soluções, a produção e lançamento desse livro tem a premissa do debate a cerca da educação dos moldes atuais, visando um salto de qualidade na perspectiva digital. Seu enredo vai desde a criação e execução de políticas públicas que beneficiem as ações nesse sentido, bem como sanar algumas duvidas em relação a um dos principais problemas enfrentados por professores em sala de aulas no ensino básico - o uso das novas tecnologias.

É inegável que a sociedade atual, a chamada "sociedade do conhecimento", produz sujeitos sociais cada vez mais plugados com o mundo virtual, um desafio para a educação e para os educadores, pois estes estão sempre em confronto com aparelhos de acesso a internet dentro das salas de aulas, muito mais potentes que muitos computadores presentes nos chamados laboratórios de informática. A presença de celulares, tablets, iphones no contexto educacional se torna um problema para a maioria dos professores, pois é um grande desafio fazer com que seus alunos se desconectem do mundo virtual. O debate sobre REA possibilita uma nova forma de pensar o planejamento das aulas e a troca de conhecimentos entre professores e alunos.

Os recursos educacionais abertos alem de trazer uma proposta de dinamização de aulas, faz com que os profissionais da educação 
repensem sua formação e suas práticas. Neste sentido, os relatos e as entrevistas que o livro traz, ajudam o leitor a questionar e também a produzir ações que deverão contribuir para a melhoria da educação como um todo, ao se verem como produtores de materiais e cada vez mais afeitos as dinâmicas próprias do mundo virtual, estarão colaborando também com a democratização desse espaço - a internet - à medida que, uma vez licenciado como livres, os materiais poderão circular com rapidez de forma global, desde que o acesso à rede também seja possível a todos.

Mais que livro um com uma temática relevante, o diferencial desse trabalho se concentra na apresentação de possibilidades reais para uma educação moderna, em conexão com o mundo virtual e cada vez mais globalizado. Auxilia a pensar em novas formatações para as aulas, situando o "aprender" nas trocas de experiências e conhecimentos entre professores e alunos. Assim, as práticas professorais podem ser direcionadas e, necessitando para isso, que seja revista também sua formação. Ou seja, muitas são as relevâncias a cerca de REA, valendo a pena conhecer e debater, para que se criem novas formas de pensar uma educação para todos. 